\title{
注染の染工場における布からみた設いと表出 \\ 一地域産業のものづくり空間におけるもの・建築・都市の関係の研究- \\ SPATIAL SETTING AND ITS APPEARANCE IN THE DYE FACTORY \\ OF CHUSEN FROM THE VIEWPOINT OF CLOTH
}

Study on Interrelation between Thing, Architecture and City in Manufacturing Space of Local Industry

安森亮雄*1, 福沢潤哉*2, 塚本琢也*2

Akio YASUMORI, Junya FUKUZAWA and Takuya TSUKAMOTO

The aim of this paper is to clarify spatial settings and townscape of the dye factory along urban river. We researched 6 dye factories in Utsunomiya, Tokyo, Hamamatsu and Osaka. First, we examined their manufacturing flow, form of cloth, setting of building elements, facilities and furniture, and we found typical spatial settings as the combination of them. Secondly, we examined external forms of the factories. Finally, we found the characteristics of townscape through appearance of spatial settings of factories. The results were the re-establishment of interrelation between things, architecture and city which have been divided by modern industries.

Keywords : Local Industry, Handicraft Manufacture, Factory, Craftsmanship, Townscape

地域産業，手工業，工場，ものづくり，都市景観

\section{1. 序}

\section{1 研究の背景と目的}

ものを作る工場や工房の建築では、素材からものを加工し生産す るための特徴的な空間がみられ、そこには人間の活動だけでなく、 ものを内包する空間の秩序を読み取ることができる。例えば、ル・ コルビュジエは、船や自動車とともにサイロや自動車工場の建築を 礼讚し、近代建築の合理性を見いだした ${ }^{1)}$ 。また、工場や産業のた めの建築は、一介の技術者によって設計されることが多いことから 「建築家なしの建築」 2) や「無名の彫刻」3) と呼ばれ、そのアノニ マス（匿名的）な意匠が着目されてきた。さらに近年では、工場建 築が近代産業遺産注 1) として評価されるとともに地域活性化に活用 され、見学や出版注2)も行われるなど関心が向けられている。この ように、ものづくりをする工場の建築には、固有の建築的特徵と都 市の空間資源としての可能性を見いだすことができると考えられる。

特に、地域産業におけるものづくりにおいては、素材の産地や交 通などの都市環境や、日照や水源などの自然環境を活かして工場が 立地し、また、機械生産だけに頼らない手工業によって生産される ことが多い。そのため、機械化された大空間ではなく、ものと、道 具や設備、建築が一体となって設えられる空間に特徵がみられ、また、 それらが都市に表出することにより都市景観の一部を形成している。
ここには、産業におけるものと、それが生産される建築、それらを 取り巻く都市の密接な関係を見て取ることができる。

こうした地域産業の中でも、染色産業の注染（ちゅうせん）は、 大量生産を前提に手作業が残る工場制手工業のひとつであり、明治 中期に考案され、手拭や浴衣などに用いる木綿の反物を、畳んで化 学染料で注ぎ染める型染めの産業である。その染工場(せんこうじょ う）は、水と原材料の綿布などを必要とするために、交通が発達し た都市の河川沿いに発達してきた。また、その工程に応じて布が広 げられたり畳まれたりするなど、生産されるものが特徵的な形で建 築空間の中で报わ机、建築もそれに応じて設えられるなど、もの・ 建築・都市が密接に関わる空間の特徵がみられる。

そこで本研究では、都市河川沿いに発達した注染の染工場を対象 として、地域産業におけるものからみた建築空間の設い注3) と、都 市空間におけるその表出の特徴を明らかにすることを目的とする注 4)。このことは、ものと、それが生産される建築、都市や自然の環 境を包括的に捉え直すことであり、近代以降の産業で分断されてき た、ものと地域の関係性を捉え直す試みとして有意義であり、その 先に今後の地域活性化を見据えることも可能なものと考えられる。

\section{2 既往研究および本研究の意義}

工場や工房を対象にその計画や意匠を検討したこれまでの研究に
*1 千葉大学大学院工学研究院 教授 ·博士 (工学)

*2 (株) INA 新建築研究所 修士(工学)
Prof., Graduate School of Engineering, Chiba Univ., Dr.Eng. Institute of New Architecture Inc., M.Eng. 
は、まず、特定の企業の工場の発展過程や、平面計画、建築構造等 の特徵を検討したものがみられる ${ }^{5,6,7)}$ 。また、特定の工場とそれが 地域に与えた影響を検討するものがみられる ${ }^{8)}$ 。これらは、いずれ もかつて稼動した特定の工場を対象に歴史的観点から検討したもの であり、本研究のように現在稼動中の工場を対象に実地調査をした ものではない。また、工場建築の意匠に着目した研究に、特定の建 築家や、特定の時期にデザインされた清掃工場の意匠について検討 するもの ${ }^{9)}$ がみられる。これに対して、本研究は、特定の設計者で はないアノニマス（匿名的）な工場の空間構成を明らかにするもの である。また、工芸や農業などの多業種の手仕事の空間を対象として、 空に着目して人とものと自然の関係を検討した報告 ${ }^{10)}$ に染物の工 房も含まれているが、本研究のように、布の形態やその変化といった、 ものの形態的な属性をもとに都市空間における表出までを扱ったも のではない。

染色や染工場に関するこ扎までの研究や報告として、筆者らは平 成 27 年度に宇都宮美術館や染工場と協㗢して、宇都宮市の注染の歴 史の発掘と、市民参加を通した新しい染めのデザインを開発するプ ロジェクトを実践した注5)。本研究は、それを一つのきっかけとして、 市内および全国の染工場を対象に建築調査を発展させたものである。 また、埼玉県立歴史と民俗の博物館により、平成 19 年度に埼玉県 を中心とする注染について調査がなされている ${ }^{14)}$ 。のように、注 染については、産地の美術館や博物館により調査されているが、本 研究のように染工場の建築に着目した研究は行われていない。また、 京染めの町家について、増改築や光環境に着目した報告 ${ }^{15)}$ があり、 そこでは伝統産業の分業における町家形式に着目しているが、近代 手工業である注染の染工場は、成立背景や工場の空間が異なり、本 研究のように布の形態や都市空間への表出に着目したものではない。

\section{2. 注染の主産地における染工場の概要}

現在の注染の主産地は栃木県宇都宮市、東京都江戸川区なぞ荒川 の一帯、静岡県浜松市、大阪府堺市の 4 都市である注6)。各地の染 工場の推移をみると（図 1 ） 注7）、1932（昭和 7）年には、宇都宮 で 61 件、東京で 132 件、浜松で 62 件、堺で 51 件みられた。第二 次世界大戦中の 1942 (昭和 17）年に発令された企業整備令により、 日常品を含めた統制経済の中で非軍需産業が整理され、染工場も全 国的に減少した。戦後は、1980 年代までは各地で一定数稼動してい たが、日常品としての手拭や和装の浴衣の需要低下、ローラーやプ リント等の機械化された安価な柄付けの技術の普及により、生産量 はさらに減少した。しかし注染の風合いは未だに需要があり、現在 は宇都宮で 3 件、東京で 4 件、浜松で 6 件、堺で 4 件が稼動している。 これらの主産地において、現在でも注染が行われ、実地調査するこ とのできる6つの染工場を対象とした注8）(表 1 ）。

まず、宇都宮(図 2 )では、近隣の真岡市が良質な木綿の産地であり、 古くから城下町として都市化し需要もあったため、注染は「宮染め」 と呼ばれる地域産業となってきた。明治後期から染工場が増加し、 現在 3 件の染工場が稼動している。このうち、中川染工場 (No.1) は、 1905（明治 38）年に創業し現在 5 代目が引き継いでいる。当初は 藍染めであったが、昭和初期から注染を主体とするようになり、現 在は年間 12 万反と多くの生産量を誇る。染工場は市内を流れる田川 の上流に立地し、広大な敷地を有している。福井染工場（No.2）は、 1912 (大正元) 年操業で、主に幟旗や、暖策、半縓等の小さなサイ ズの捺染注9)を行っている。注染は副次的であるため生産量は少なく、 田川沿いの市街地に立地する。エバマン染工場（No.3）は、注染の 最盛期である 1934 （昭和 9）年に操業した。田川支流の釜川沿いの 市街地にあったが、都市化の進行により、戦後に市の西部に移転した。
Table 1 Outline of dye factory 表 1 染工場の概要

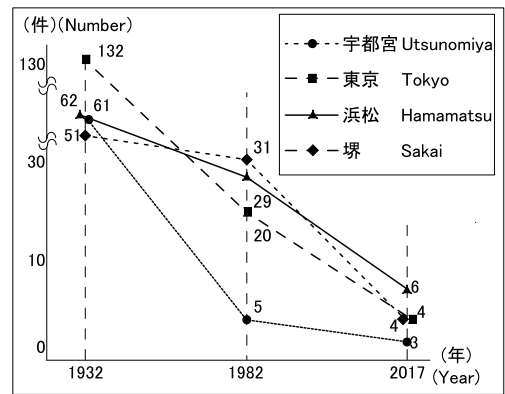

Fig.1 Transition of dye factory in each city 図 1 各都市における染工場数の推移

\begin{tabular}{|c|c|c|c|c|c|c|}
\hline $\begin{array}{l}\text { 染工場名 } \\
\text { Dye factory name }\end{array}$ & $\begin{array}{l}\text { 所在地 } \\
\text { Place }\end{array}$ & \begin{tabular}{|l|}
$\mid$ 創業年 \\
Founding \\
year
\end{tabular} & Site area & $\begin{array}{l}\text { 延床面積 } \\
\text { Total foor } \\
\text { area }\end{array}$ & $\mid$\begin{tabular}{|l} 
建ぺい率 \\
Coverage \\
rate
\end{tabular} & \begin{tabular}{|l|} 
年間生産量 \\
Annual output
\end{tabular} \\
\hline $\begin{array}{l}\text { 1.中川染工場 } \\
\text { Nakagawa } \\
\text { Dye factory }\end{array}$ & $\begin{array}{l}\text { 栃木県宇都宮市 } \\
\text { Tochidi Pref. } \\
\text { Utsunomiya city }\end{array}$ & 1905 & $4900 \mathrm{~m}^{2}$ & $1400 \mathrm{~m}^{2}$ & $37 \%$ & $\begin{array}{r}120000 \text { (反) } \\
\text { (Fabric) } \\
\end{array}$ \\
\hline $\begin{array}{l}\text { 2.福井染工場 } \\
\text { Fuuui } \\
\text { Dye factory }\end{array}$ & $\begin{array}{l}\text { 栃木県宇都宮市 } \\
\text { Tochidi Pref. } \\
\text { Utsunomiya city }\end{array}$ & 1912 & $660 \mathrm{~m}^{2}$ & $235 \mathrm{~m}^{2}$ & $55 \%$ & $\begin{array}{r}5000 \text { (反) } \\
\text { (Fabric) }\end{array}$ \\
\hline $\begin{array}{l}\text { 3.Iバマン染工場 } \\
\text { Ebaman } \\
\text { Dye factory }\end{array}$ & $\begin{array}{l}\text { 栃木県宇都宮市 } \\
\text { Tochidi Pref. } \\
\text { Utsunomiya city }\end{array}$ & 1934 & $1120 \mathrm{~m}^{2}$ & $390 \mathrm{~m}^{2}$ & $36 \%$ & $\begin{array}{r}12000 \text { (反) } \\
\text { (Fabric) }\end{array}$ \\
\hline $\begin{array}{l}\text { 4.村井染工場 } \\
\text { Murai } \\
\text { Dye factory }\end{array}$ & $\begin{array}{l}\text { 東京都江戸川区 } \\
\text { Tokyo. } \\
\text { Edogawa ward }\end{array}$ & 1936 & $490 \mathrm{~m}^{2}$ & $410 \mathrm{~m}^{2}$ & $70 \%$ & $\begin{array}{r}70000 \text { (反) } \\
\text { (Fabric) } \\
\end{array}$ \\
\hline $\begin{array}{l}\text { 5.二橋染工場 } \\
\text { Nihashi } \\
\text { Dye factory }\end{array}$ & $\begin{array}{l}\text { 静岡県浜松市 } \\
\text { Shizuoka Preff. } \\
\text { Hamamatsu city }\end{array}$ & 1927 & $960 \mathrm{~m}^{2}$ & $1200 \mathrm{~m}^{2}$ & $84 \%$ & $\begin{array}{r}24000 \text { (反) } \\
\text { (Fabric) }\end{array}$ \\
\hline $\begin{array}{l}\text { 6.㔹二染工場 } \\
\text { Nakani } \\
\text { Dye factory }\end{array}$ & $\begin{array}{l}\text { 大阪府堺市 } \\
\text { Osaka. } \\
\text { Sakai city }\end{array}$ & 1966 & $850 \mathrm{~m}^{2}$ & $937 \mathrm{~m}^{2}$ & $82 \%$ & $\begin{array}{r}96000 \text { (反) } \\
\text { (Fabric) }\end{array}$ \\
\hline
\end{tabular}

Table 2 Site size and building range

表 2 敷地規模と建物範囲 (6 dye factories)

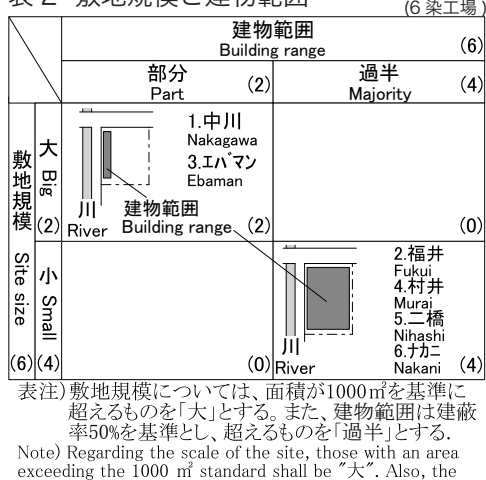

Note) Regarding the scale of the site, those with an area
exceeding the $100 \mathrm{~m}^{2}$ the the one that exceeds the building coverage ratio is "過半".

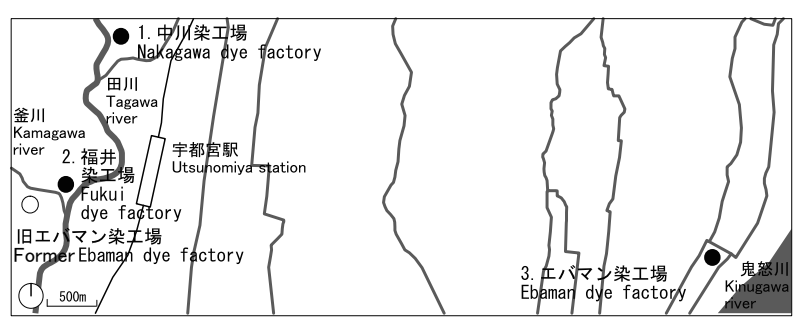

Fig.2 Dye factory in Utsunomiya

図 2 宇都宮市の染工場

図 2〜5 凡例) 地図中

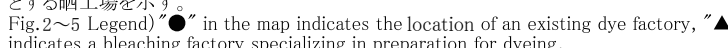

in the map indicates the location of an existing

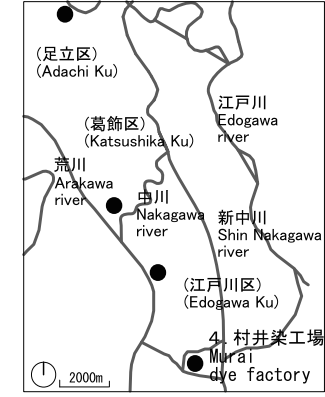

Fig.3 Dye factory in Tokyo 図 3 東京都の染工場

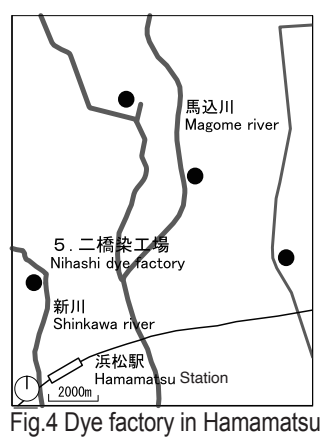

Fig.4 Dye factory in Hamam
园 4 浜松市の染工場

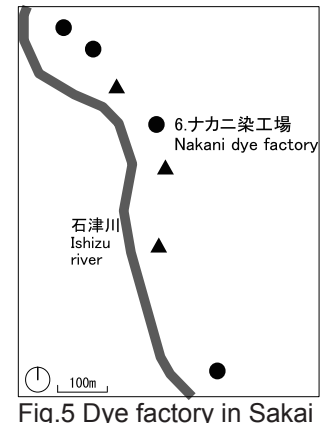

図 5 堺市の染工場 
次に、東京（図３）では、近世から浴衣等の生産により染色産業 が発達した。注染は、江戸川区、葛飾区、足立区などの荒川流域で 発達し、現在 4 件の染工場が稼動している主１0)。このうち、村井染 工場（No.4）は、注染の最盛期の $1936 （$ 昭和 11）年に操業し、今 回調査した染工場の中では、敷地が最も小さい。

浜松（図4）では、もともと綿織物産業が盛んであり、1923（大 正 12）年の関東大震災後に、東京の職人が移住し、馬込川の流域に 染工場が発達した。昭和 40 年代まで隆盛を誇つたが、市街地の再 開発等により染工場が減少し、現在は 6 件が稼動している湦11)。こ のうち、二橋染工場（No.5）は、1927（昭和 2) 年操業で、工場面 積は宇都宮の中川染工場の次に大きい。注染が主であるが、大型機 械を導入した浸染注12)も行っているため、注染の生産量としては中 程度である。

最後に、堺（図 5）は、明治中期に注染が発祥した地である。古 くから大阪に繊維問屋街があり、摂津や河内などの木綿の産地にも 近く、布を洗う晒（さらし）工場が元々あったことから、石津川沿 いに染工場が発達した。現在、他の都市と同様に染工場は減少し、 4 件が残るのみである注13)。対象としたナカ二染工場（No.6）は、 1966 (昭和 41) 年操業で、今回調査した染工場の中で最も新しく、 生産量も宇都宮の中川染工場に次いで多い。

これらの染工場の立地についてまとめると（表 2 ）、いずれも河川 や水路の近くに立地している。宇都宮の中川染工場（No.1）やエバ マン染工場（No.3）のように、郊外で敷地が大きく、外部空間を伴っ て工場建物が敷地の一部に建つものと、宇都宮の福井染工場（No.2） や、東京の村井染工場 (No.4)、浜松の二橋染工場 (No.5)、堺の ナカ二染工場（No.6）のように、市街地に立地し小規模な敷地全体 に工場の建物が建つものという2つの傾向に大別される。こうした 立地は、以下の章で検討する、染工場における工程の配置や、都市 への表出に関わりがあると考えられる。これらの 6 つの染工場につ いて、実地調査において建物の実測により現況図を作成して配置等 を記録し、また、工場の工程や沿革についての聞取り調査を行った。

\section{3. 注染の工程}

本章では、染工場における工程を捉える。注染の工程は、次のよ
うに大きく分けて 6 つの段階と 25 の工程に整理できる (表 3) ${ }^{\text {注 } 14) 。 ~}$

まず、生地の般入・保管 (表 3, A ) の段階では、生地を搬入し (1) 、 保管する ( (3))。次に、染色前準備 (B) では、しわや污れを落とし 染めやすくするために、巻かれた反物を解いて浸透液に浸す精錬 (5) を行い、屋外の櫓（やぐら）で乾燥する ( (6) )。その後、室内へ運ば れ、しわを取るため、再び棒状に丸巻きされる( (8))。

染色 ( C ) では、布を畳みながら防染糊を置く型付け (12))をし、 染色液を注ぎ染色 ( 13) する。染色後洗い ( D ) では、余分な染料を 落とすため、流水の水槽で洗い ( 14) 、脱水機で脱水される ( 15) 。

製品の仕上げ・加工 ( E ) では、櫓で染布を乾燥 ( (16) ) し、丸巻き (19) をした後、製品として手拭いに加工 ( 222) される。最後の製品の保管・ 搬出 (F) の工程では、出荷まで製品を保管し (23)、搬出 ( (25) )される。

以上のように、注染では様々な工程の中で、布が、巻かれた状態 や、伸ばした長い状態、染色のために畳まれた状態など、多様な形 態をとるのが特徵である。また、これらの工程における布の状態は、 布の保管 (表 3 , 保 ) ・ 布の加工 (加) ・ 次の工程への布の移動 (移) の 3 種に大別される。このうち、型付け ( 12) ) から染色後の乾燥 ( (16) ) までや丸巻き (8) は、いずれの染工場においても共通してみられる。 その一方で、精錬 ( (5) ) は、堺や浜松では、近隣に専業とする晒工 場があるため、分業が成立し省略されている。同様に、製品加工 ( (22) ) も整理工場への委託により、省略されている場合もみられた。

\section{4. 染工場の設い \\ 4.1 布の形態}

本章では、染工場の建築空間と布との関わりについて分析する。 前章でみたように、注染の工程では、丸巻きされた棒状の形状や、 一反に延ばされた長い形状など、さまざまな布の形態がみられ、そ れらは、染工場の建築、設備、家具等と関わりがあると考えられる。 そこでまず、布の形態について整理する(表 4 )。

注染で染められる木綿生地は、通常、着物一着に用いられる一反 の布を用いる（幅約 $37 \mathrm{~cm}$ 、長さ約 $12.5 \mathrm{~m}$ )。これが、棒状に丸巻き されたもの（表 $4, \mathrm{Sa} ）$ と、丸巻きを数本まとめて保管や運搬をし やすくしたタイコと呼ばれる形態 $(\mathrm{Sb})$ は、布の幅（約 $37 \mathrm{~cm} ）$ の 寸法をもつ比較的小さなサイズと言える。次に、一反をゆるく丸め

Table 3 Process of each dye factory

表 3 各染工場の工程

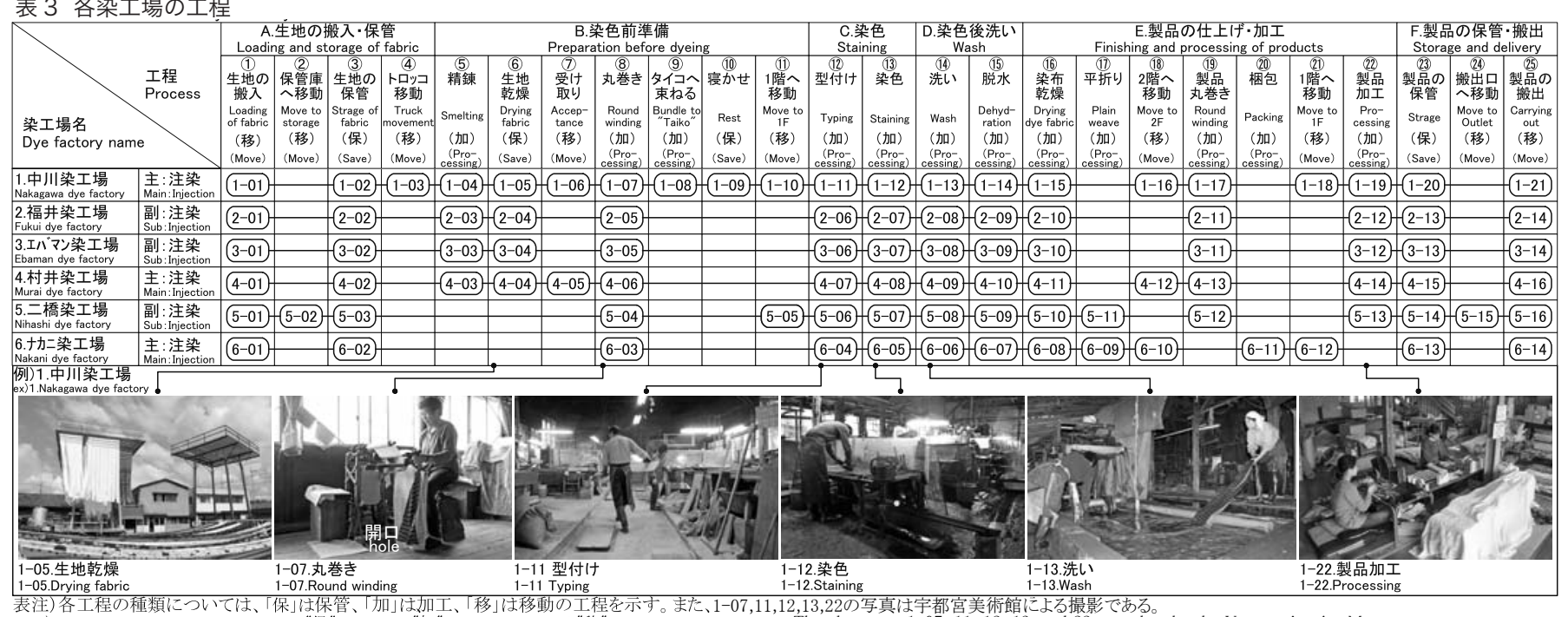

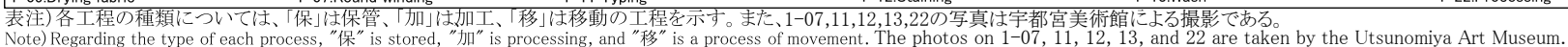


たもの (Ma)、重悋て染めるために平折りしたもの $(\mathrm{Mb}) 、$ 手拭と して切られたもの (Mc) は、中程度のサイズであり、長さ約 $90 \mathrm{~cm}$ （1 尺）が標準的な平折りと手拭の寸法である。これらの中サイズは、 多くの工程でみられるものである（6 染工場の合計 95 工程中、53 工程)。一反の布を延ばした長さ（約 $12.5 \mathrm{~m} ）$ の形態 (L) は大サイ ズであり、垂直に吊るされる場合と、水平に張る場合がある。染工 場では、これらの各形態が、単体で置かれている工程と、複数で置 かれている工程がある。また、一反から丸巻き $(\mathrm{L} \rightarrow \mathrm{S})$ 、丸巻きか ら平折り $(\mathrm{S} \rightarrow \mathrm{M})$ のように、布の形態を変化させる工程もある。

調査した染工場で比較すると、丸巻き $(\mathrm{Sa})$ 、丸め $(\mathrm{Ma})$ 、平折り (Mb) は、どの染工場でも見られるが、丸巻きを直径 $50 \sim 60 \mathrm{~cm}$ 程度にまとめた夕イコ（Sb）は宇都宮の中川染工場（No.1）のみで 見られる。生産量が多く大規模な工場において独自に工夫された形 態と考えられる。また、二橋染工場（No.5）とナカ二染工場（No.6） では精錬の工程が無いため、一反の長さから丸巻きへの変化 $(\mathrm{L} \rightarrow \mathrm{S})$ はみられない。このように各染工場で布の形態にも特徴がみられた。 4.2 染工場における建築部位と設備・家具

染工場では、様々な布の扱い方に応じて、床、壁、天井、屋根な どの建築の部位が工夫され、また、布を干す櫓（やぐら）や作業台 などの特徴的な設備と家具が配置されている。

まず、建築部位の特徵について整理する ( 表 5 )。床では、2 階床 に開口を設ける場合があり、布を垂らして丸巻きをするためのもの である。また、2 階から 1 階への滑り台は、丸巻きや夕イコ状の布 を落として移動するものである。床の仕上げとして、おが屑や砂を 敷いているのは、染色の前に糊付した布を床に置く際に保護するた めである。また、壁の開口部は、手作業し易いようにその前方や上 方に設けられ、高空になっている場合もみられた。また、染色で用 いる木枠やへラ等の道具をまとめて架けてある壁面も特徴的である。 屋根は、換気のための越屋根や、屋上で作業するためのデッキがあり、 半屋外で作業するための庇も多くみられた（6 染工場中、 4 工場）。

次に、作業で用いられる家具や設備について、その種類と、それ らが複数反復して配列しているかをあわせて検討した (表 6 )。まず、 染工場で特徵的なのは、布を干す櫓である。通常、自然乾燥するた めに屋外に設置されるが、屋内にある場合もある。また、布を水平 に乾燥する干し竿は、敷地が広い中川染工場（No.1）のみでみられ た。布を洗う水槽は、いずれの染工場でも設置されている。以上の 設備は、手作業で行うものであるが、脱水機、昇降機、洗い機、丸 巻機などの機械設備も見られた。また、型付け、染色、製品加工な ぞに用いる作業台は、ぞの染工場でも複数反復して配列され、複数 の職人が同時に作業できるようになっている。さらに、作業する人 の姿勢について、立位か座位かを整理し検討したところ、立位が多く、 座位では椅座位と平座位がみられた (表 7 )。

\section{3 染工場における設いのパタン}

染工場のものづくり空間における、ものと建築の関わりについて まとめる。本章 1 節で整理した布の形態が、2 節で検討した建築の 部位や家具・設備とどのように対応し、布の保管・加工・移動等の 工程に位置づいているかを検討し、設いのパタンを抽出した (表 8 )。

まず、小サイズの布で、丸巻き $(\mathrm{Sa})$ の布を保管するために複数並 べる設い (S-1) は、全ての染工場で見られる。また、丸巻きをまと めたタイコ $(\mathrm{Sb})$ を滑り台を用いて上階から下階に移動する設い $(\mathrm{S}-2)$
は、生産量の多い中川染工場（No.1）に特有であり、多くの布をま とめて扱うため、ものと建築部位の呼応関係が工夫されたと考えら れる。

次に、中サイズの布は多くの工程にあり、設いも多岐にわたる。 まず、建築部位と関わる設いでは、多くの染工場で、庇の下で平折 りした布 $(\mathrm{Mb})$ が般入や搬出される状態 (M- 建築 1) が見られた。も のづくりにおいて庇の半外部空間を活用する設いの典型と言える。 また、屋上を使って丸めた布 $(\mathrm{Ma})$ を投げ渡す設い (M- 建築 2) は、 一部の染工場で建築を立体的に活用しているものである。次に、中 サイズの布が設備と関わる設いでは、平折りされた布 $(\mathrm{Mb})$ を昇降 機で移動するもの (M- 設備 1) があり、先に述べた丸巻きの布とすべ り台の設い (S-2) が機械化されたものと言える。丸めた布 $(\mathrm{Ma}) を 、$

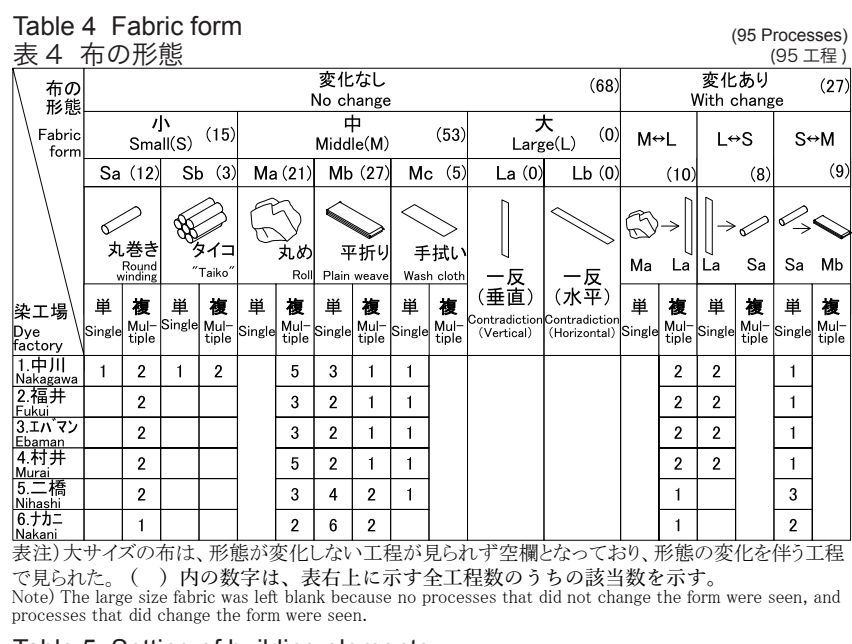

Table 5 Setting of building elements

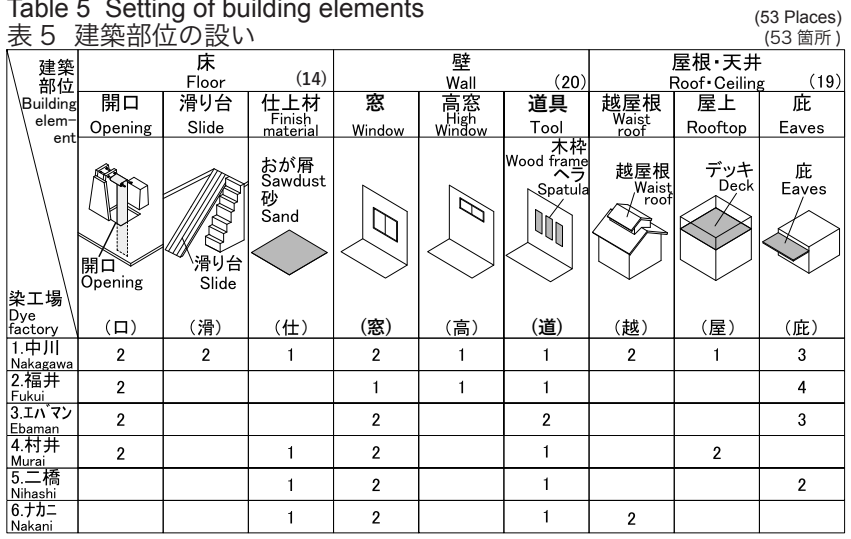

Table 6 Setting and repeat of facilities and furniture

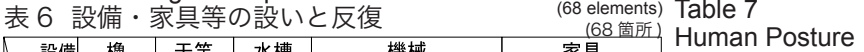

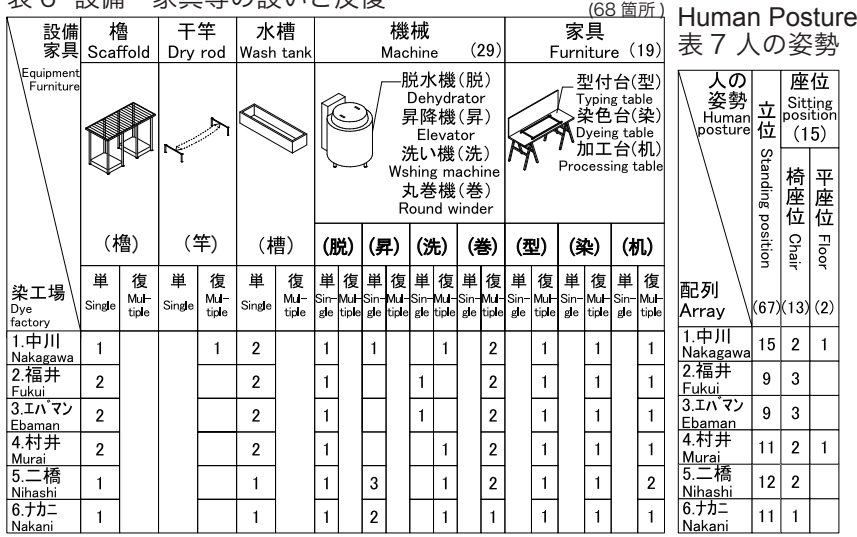
表注) 表7の「人の姿勢」は、全95工程を対象にカウントした。うち13工程は、生地の保管などの通常、 人がいない工程である。

Note) The "human posture" in Table 7 was counted for all 95 processes. Thirteen of these processes are
usually unmanned, such as dough storage. 
染色前に水槽で漬ける設い (M- 設備 2) や、染色後に水槽で洗い機 を用いて洗う設い $(\mathrm{M}$ - 設備 3$) 、$ 脱水機で脱水する設い $(\mathrm{M}$ - 設備 4) は、 いずれも水を使う染色の工程において、布というものと設備が呼応 している。さらに、平折りの布 $(\mathrm{Mb})$ が染色台に置いていある設い $(\mathrm{M}-$ 家具 1)、手拭いとして切られた布 $(\mathrm{Mc})$ が製品加工され机上にある 設い (M- 家具 2) は、いずれも職人が布を台の上で扱う工程で見ら れるものである。

以上の布と建築の組合せは、布の形態が一定のまま扱われる工程 でみられるのに対して、以下は、布の形態が変化する設いである。 染色前に布に糊で型付けする工程では、丸巻きされた布 (Sa) を型 付台の上で平折り $(\mathrm{Mb})$ へと形態変化させる $(\mathrm{SM}$ 変化)。ここでは、 糊付けした布を保護するために、床におが屑や砂が敷かれ、壁には 採光用の高窓や、型付けで用いる木枠やへラなどの道具が架けられ ており、職人が布を作業しやすい環境として、様々な要素が組み合 わされた複合的な設いが成立している。また、丸巻きの工程では、 垂直に伸ばされた一反の布 $(\mathrm{La})$ を丸巻き $(\mathrm{Sa})$ へ形態変化させる (LS 変化)。丸巻機が置かれる場所は、布を吊るすことができるよう に 2 階の床に開口が開けられ、空際にある。布の形態変化と建築部 位が呼応し、染色前と染色後に二度用いられる設いである。最後に、 布を乾燥する工程では、丸めた布 $(\mathrm{Ma})$ を垂直に伸ばされた一反 (La) へと形態変化させる (ML変化)。ここでは、特徵的な構築物として 櫓が用いられ、通常、下にいる職人が丸めた布をひもに結び、上に いる職人がひもを引き上げて布を干すという作業が行われる。丸巻 きの工程と同じく、通常、染色前と染色後に二度用いられる設いで ある。これらの布の形態が変化する設いのパタンでは、建築部位や、 家具、設備が工夫され、染工場の特徵が表れていると言える。

\section{5. 染工場の外形構成}

本章では、染工場の外形構成について検討する。染工場は複数の 建物でできている。まず、その階数 (表 9 ) について検討すると、い ずれの染工場も平屋と 2 階建ての双方があり、平屋を主体とする中 川染工場（No.1，7 棟中、平屋 5 棟）や、2 階建てを主体とする二 橋染工場（No.5， 7 棟中、2 階建て 5 棟）などの特徵がみられた。 一方で、福井染工場（No.3）は、3 棟と少ない棟数で限られた敷地 に立地している。また、ナカニ染工場（No.6）のように、平屋と 2 階建てに加えて、3 階建てが 1 棟あることで、限定された敷地の中 で立体化しているものも見られる。

次に、こうした建物の屋根形状について検討すると (表 10 )、切 妻や片流孔などの勾配屋根が比較的多い（21 棟／全 31 棟)。また、 建物の構造 (表 11 ） は、木造の $($ No.2, No.4)、鉄骨造のみ（ No.5)、また、木造の建物と鉄骨造の建物をあわせもつ染工場（No.1， No.6) が見られた。特に、宇都宮に立地する染工場（No.1，No.3） では、市内で産出する大谷石（おおやいし）でできた石造の建物が あり、地域産業のものづくりの空間が地域の素材で作られるという 特徵がみられた。

これらの外形の特徵を合わせて、染工場の建物の外形構成のパ夕 ンを整理した (表 12 )。平屋で勾配屋根の建物（ア）は、全建物の 約 $1 / 3$ と比較的多くみられ (11 棟／全 31 棟)、構造は木造が多い。 平屋で陸屋根の木造建物 (イ)もある。また、2 階建てで勾配屋根 の建物（ウ）も比較的多く（10 棟／全 31 棟）、こちらは鉄骨造が
Table 8 Pattern of setting in dye factory

表 8 染工場における設いのパタン

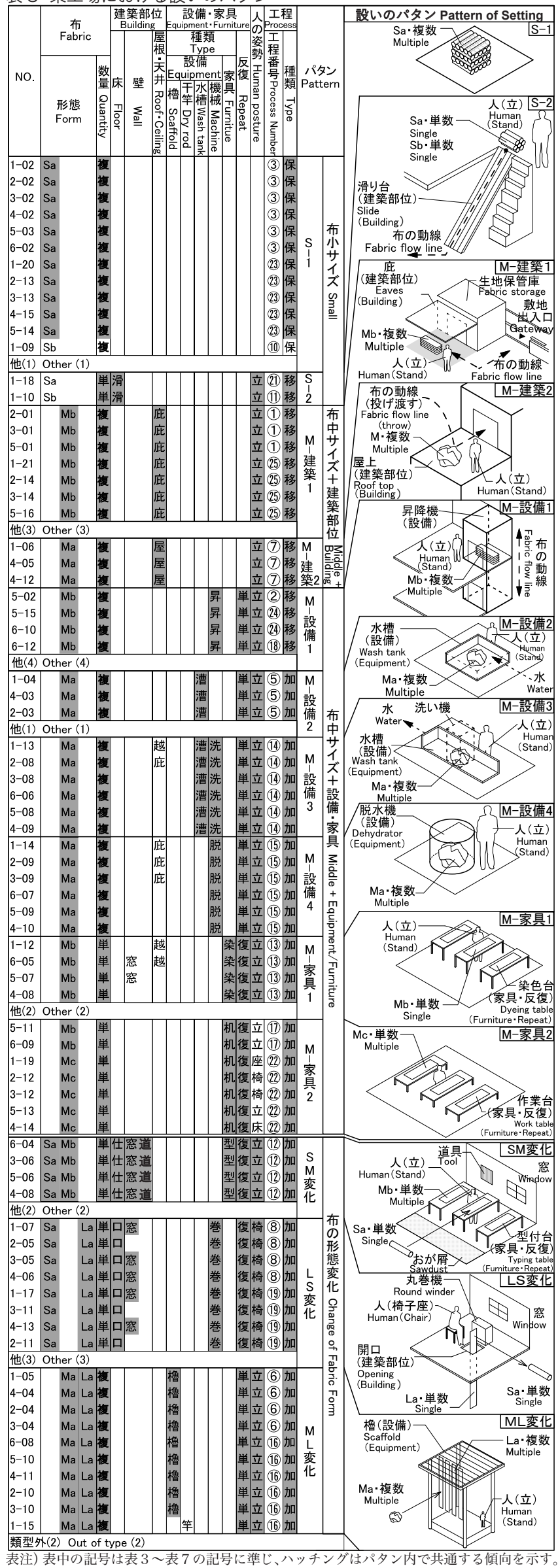


主となっている。2 階建ての陸屋根（エ）も鉄骨造が多い。3 階建 ては、陸屋根の鉄骨造で、先に述べたように、ナカニ染工場（No.3） のみで 1 棟みられた。全体として、平屋と 2 階建てを主体とする低 層で、鉄筋コンクリート造はなく木造や鉄骨造等の軽快な構造でつ くられ、勾配屋根が多いという傾向の中でこれらのパタンができて おり、本研究で扱った染工場の外形の傾向を示している。

\section{6. 染工場におけるもの・建築・都市の関係とその表出}

これまでの分析を総合することにより、注染の染工場における、 もの・建築・都市の関係を明らかにする。すなわち、工程（3 章） に沿って、様々な形態の布が、建築部位や、設備、家具等と対応し

Table 9 Number of stories 表 9 階数

\begin{tabular}{|c|c|c|c|c|}
\hline & $\begin{array}{l}\text { 棟数 } \\
\text { Buidings }\end{array}$ & 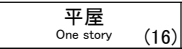 & \begin{tabular}{ll|} 
2階建て & \\
Two-story & $(14)$ \\
\end{tabular} & $\begin{array}{lll}\text { 3階建 } & \\
\text { Three-story } & (1) \\
\end{array}$ \\
\hline $\begin{array}{l}\text { 1.中川染工場 } \\
\text { Nakagawa Dye factory }\end{array}$ & 7 & $\begin{array}{l}\text { 1- I }, 1-\mathrm{IV}, 1-\mathrm{V} \\
1-\mathrm{VI}, 1-\mathrm{VII}\end{array}$ & $1-$ II, $1-$ III & \\
\hline $\begin{array}{l}\text { 2.福井染工場 } \\
\text { Fukui Dye factory }\end{array}$ & 3 & 2-III & 2- I ,2-II & \\
\hline $\begin{array}{l}\text { 3.エバマン染工場 } \\
\text { Ebaman Dye factory }\end{array}$ & 4 & $3-\mathrm{I}, 3-\mathrm{II}, 3-\mathrm{IV}$ & $3-$ III & \\
\hline $\begin{array}{l}\text { 4.村井染工場 } \\
\text { Murai Dye factory }\end{array}$ & 4 & 4- I , 4- II, 4-IV & 4-III & \\
\hline $\begin{array}{l}\text { 5.二橋染工場 } \\
\text { Nihashi Dye factory }\end{array}$ & 7 & $5-\mathrm{I}, 5-\mathrm{VII}$ & $\begin{array}{l}\text { 5-I, 5-II, } \\
5-\mathrm{IV}, 5-\mathrm{V}, 5-\mathrm{VI}\end{array}$ & \\
\hline $\begin{array}{l}\text { 6.ナカ二染工場 } \\
\text { Nakani Dye factory }\end{array}$ & 6 & $6-$ II , 6-III & $6-\mathrm{IV}, 6-\mathrm{V}, 6-\mathrm{VI}$ & $6-\mathrm{I}$ \\
\hline
\end{tabular}
表注) 表中の番号は、「工場一建物番号」を示す(建物番号は図 6 参照、以下同様)。
Note) The numbers in the table indicate "Factory - Building number" (see fig.6, as follows).

\section{Table 10 Roof Shape}

表 10 屋根形状

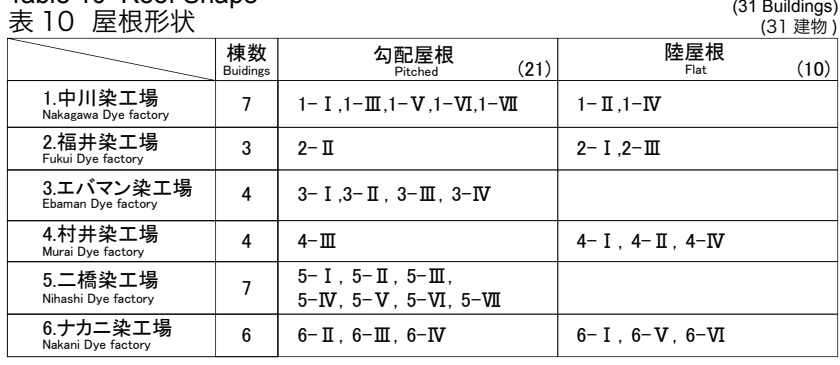

\section{Table 11 Structure}

\section{表 11 構造種別}

\begin{tabular}{|c|c|c|c|c|}
\hline$\gamma$ & $\begin{array}{l}\text { 棟数 } \\
\text { Buidings }\end{array}$ & $\begin{array}{l}\underset{\text { 木造 }}{\text { Wooden }}(W) \\
\text { W (13) }\end{array}$ & $\begin{array}{c}\text { 鉄骨造（s） } \\
\text { Steel }\end{array}$ & 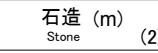 \\
\hline $\begin{array}{l}\text { 1.中川染工場 } \\
\text { Nakagawa Dye factory }\end{array}$ & 7 & $1-\mathrm{IV}, 1-\mathrm{V}, 1-\mathrm{VI}, 1-\mathrm{VII}$ & $1-$ II, $1-$ III & $1-I$ \\
\hline $\begin{array}{l}\text { 2.福井染工場 } \\
\text { Fukui Dye factory }\end{array}$ & 3 & 2- I ,2- II ,2-III & & \\
\hline $\begin{array}{l}\text { 3.エバマン染工場 } \\
\text { Ebaman Dye factory }\end{array}$ & 4 & & 3- I ,3- II,3-III & $3-\mathrm{IV}$ \\
\hline $\begin{array}{l}\text { 4.村井染工場 } \\
\text { Murai Dye factory }\end{array}$ & 4 & 4- I ,4- I I ,4-II, 4-IV & & \\
\hline $\begin{array}{l}\text { 5.二橋染工場 } \\
\text { Nihashi Dye factory }\end{array}$ & 7 & & $\begin{array}{l}\text { 5- I ,5- II,5-III,5-IV } \\
5-\mathrm{V}, 5-\mathrm{VI}, 5-\mathrm{VII}\end{array}$ & \\
\hline $\begin{array}{l}\text { 6.ナ力二染工場 } \\
\text { Nakani Dye factory }\end{array}$ & 6 & $6-$ I I ,6-III & $6-\mathrm{I}, 6-\mathrm{IV}, 6-\mathrm{V}, 6-\mathrm{VI}$ & \\
\hline
\end{tabular}

Table 12 Building pattern of dye factory 表 12 染工場の外形パタン

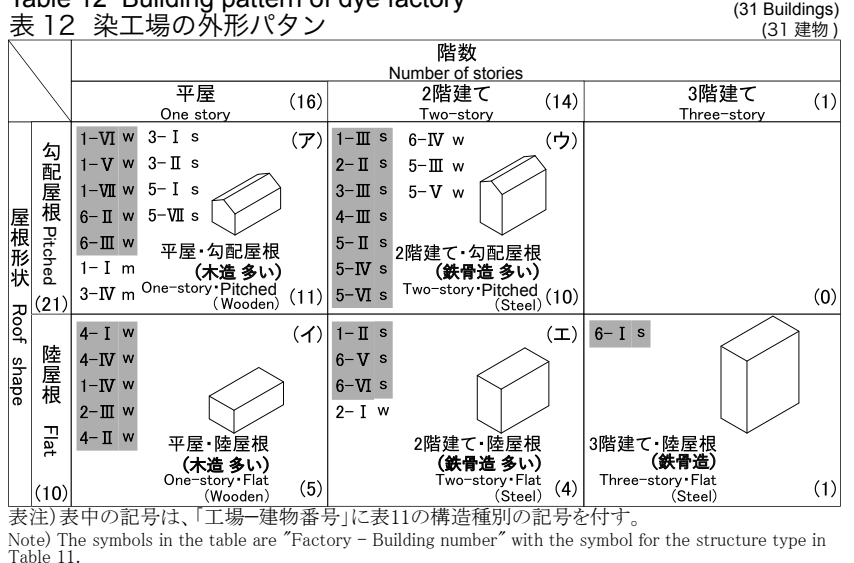

て設えられ（４章)、染工場の外形（５章）の中で位置づいており、 その全体像を明らかにする。ここでは、それらが都市空間へどのよ うに表出しているかを含めて、各染工場の特徵を述べる（図 6 )。

中川染工場（No.1）：本染工場は、敷地面積、延床面積、生産 量ともに最大で（表 1)、宇都宮の田川の上流に立地している。広 大な敷地に、平屋を主体とする建物（II，IV〜VII）が列状に並び、 外部空間が取られている。まず、生地が搬入されると、敷地入口に ある平屋で勾配屋根をもつ石造の倉庫（I）に、丸巻きが積まれた 状態（S-1）で保管される (02)。大谷石が産出する宇都宮では、石 造倉庫や石蔵は町並みを構成する要素であり、地域の町並みに溶け 込みながら、ものづくりの空間が位置付いている。この倉庫には庇 が付いており（M- 建築 1)、最盛期にはトロッコに積み込んで、生 地漬込場（IV）へと運ばれた。そこで丸めた状態で水槽（M- 設備 2) で精錬（04）された布は、隣にある櫓で、延ばされ（ML変化）、 乾燥される $(05)$ 。この作業は毎朝行われ、櫓に吊るされた布は、 前面道路からは石造倉庫の奥に、田川からは工場の建物越しに、眺 めることができる。乾いた布は、丸めて生地漬込場の屋上のデッキ （M- 建築 2）に投げ込まれ（06）、隣の建物（III）の 2 階へ運ばれる。 そこで、布は、床の開口に吊るされ、丸巻機で巻かれる (LS 変化, 07, 表 3 の 1-07. 丸巻きの写真, 表 5 の床の開口の図)。丸巻きさ れた布は、束ねてタイコ状にされ、滑り台で 1 階に運ばれる (S-2)。

ここから、染色の工程に入るため、布は隣の糊付場 $(\mathrm{V})$ へと移 される。ここでは、まず、丸巻きの布を折り畳んで (SM 変化)、 机の上で型で糊を付ける (11)。机が 10 台以上並び、多くの職人 が作業する大空間であり、床には糊付けした布を保護するおが屑が 敷かれ、壁には作業に適した空や道具があるなど、複合的な設いが みられる。この建物は、中川染工場が戦後に現在地に移転した際に、 木造平屋の兵舎を引き取って再利用したものであり、連空によって 通風と採光が確保されている。型付けされた布は、隣の紺屋（VI） で染色される（12）。ここも複数の机が並ぶ大空間で、越屋根となっ ている（M- 家具 1)。染められた布は、隣の水場（VII）で後洗いさ れる (13)。この建物は敷地の一番奥にあり、田川から水路が引き 込まれ、その水が水槽に使われている（M-設備 3$)$ 。

染色後の布は、広い敷地を活用して干竿に水平に干される (15)。 ここでは、染色前に櫓で干される布（05）とともに、染色前と染色 後の布が同時に外部空間に表出する。乾燥した布は、今度は地上で 建物に運ばれ、丸巻きをするために昇降機で 2 階へと運ばれる（M設備 1 )。この建物（III） は、ここまで見てきたように、丸巻きす るために二度通過し $(07,17) 、$ 唯一 2 階建てとなっている。この ことから、工程および規模の点で中心的な建物であると言える。丸 巻きされた布は、今度は一本ずつ別の滑り台で 1 階に下ろされ、加 工場（II）へと運ばれる。そこで机の上で手拭いの長さにカットさ れ（M- 家具 2)、製品となる（19）。製品となった布は、再び石造 倉庫（I）に保管され（20)、最後に搬出される。

以上のように、中川染工場では、広大な敷地の中で、地域の町並 みを形成する石造倉庫（I）を起点と終点として、列状の平屋の建 物の中で 2 階建ての建物（III）が工程の中心となり、櫓や竿で干さ れる布の設いが、道路側や河川側に表出している。

福井染工場（No.2）：本染工場は、延床面積や注染の生産量が 最小であり、中川染工場と同じ田川沿いで、より中心の市街地に立 
地している。幹線道路と河川沿いの小道に二面接道し、それらを繋 ぐ敷地内通路の両側に、3 棟と少数の建物が建つ。幹線道路に面す る建物（I）の一部が店舗になっており、生地は丸巻き（S-1）の 状態で、店舗と同じ建物に運ばれ保管される $(02)$ 。そこから、敷 地内通路を通り、河川側にある水槽で精錬され（M-設備 2,3)、外 階段を登って川側の建物上部（III）の櫓で乾燥される (04)。幹線 道路には工程が表出せず、川側に水槽や櫓などの設備の設いがあり、 中心市街地の狭小な敷地において、道路側の店舗と河川側の布を扱 う設いによって、二面性のある風景を形成している。乾燥された布 は、2 階に取り込まれ、やはり開口の開いた床を利用して丸巻き（LS 変化）される（05）。丸巻きされた布は、内部階段で 1 階の染色場 に運ばれ、型付けされ (06)、1 台のみ置かれた台の上で染色され る (07)。櫓と染色場が上下に積層することで、乾燥と染色の工程 $(04$
〜07）がコンパクトに凝縮されている。染色後は、再び水槽で洗わ れ、櫓で干される (10)。中川染工場（No.1）では、地上で干され たのに対して、染色前と同じ櫓が用いられる。再度丸巻きされた布は、 敷地内通路を通って、店舗の裏の加工場で手拭いに加工され（12）、 再び幹線街路の方へ出荷される。

以上のように、福井染工場では、狭小な敷地において、幹線道路 側に店舗、河川側に洗いや乾燥の設備のある設いが表出し、二面性 のある都市の風景を形成している。

エバマン染工場（No.3）：本染工場は、宇都宮の郊外に立地し ており、中川染工場に次いで広い敷地を有する。角地で二面接道し、 道路を介して細い水路に面する。そこに、4 棟の建物が外部空間を 挟んで配置されている。生地はやはり丸巻き（S-1）の状態で、敷地 入口に近い建物（I ）で保管される (02)。その後、外部空間を通つ

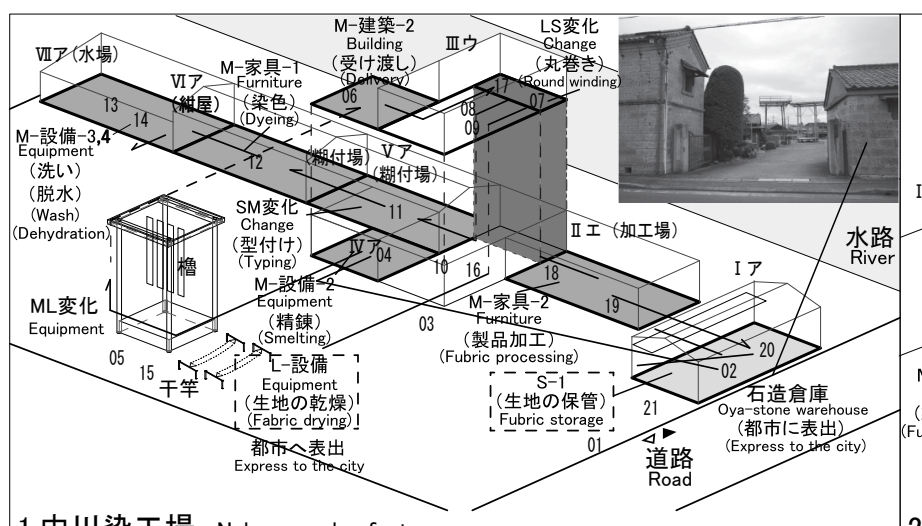

1.中川染工場 Nakagawa dye factory

〈列状の工場建物の前面の外部空間における布を干す設いの表出〉
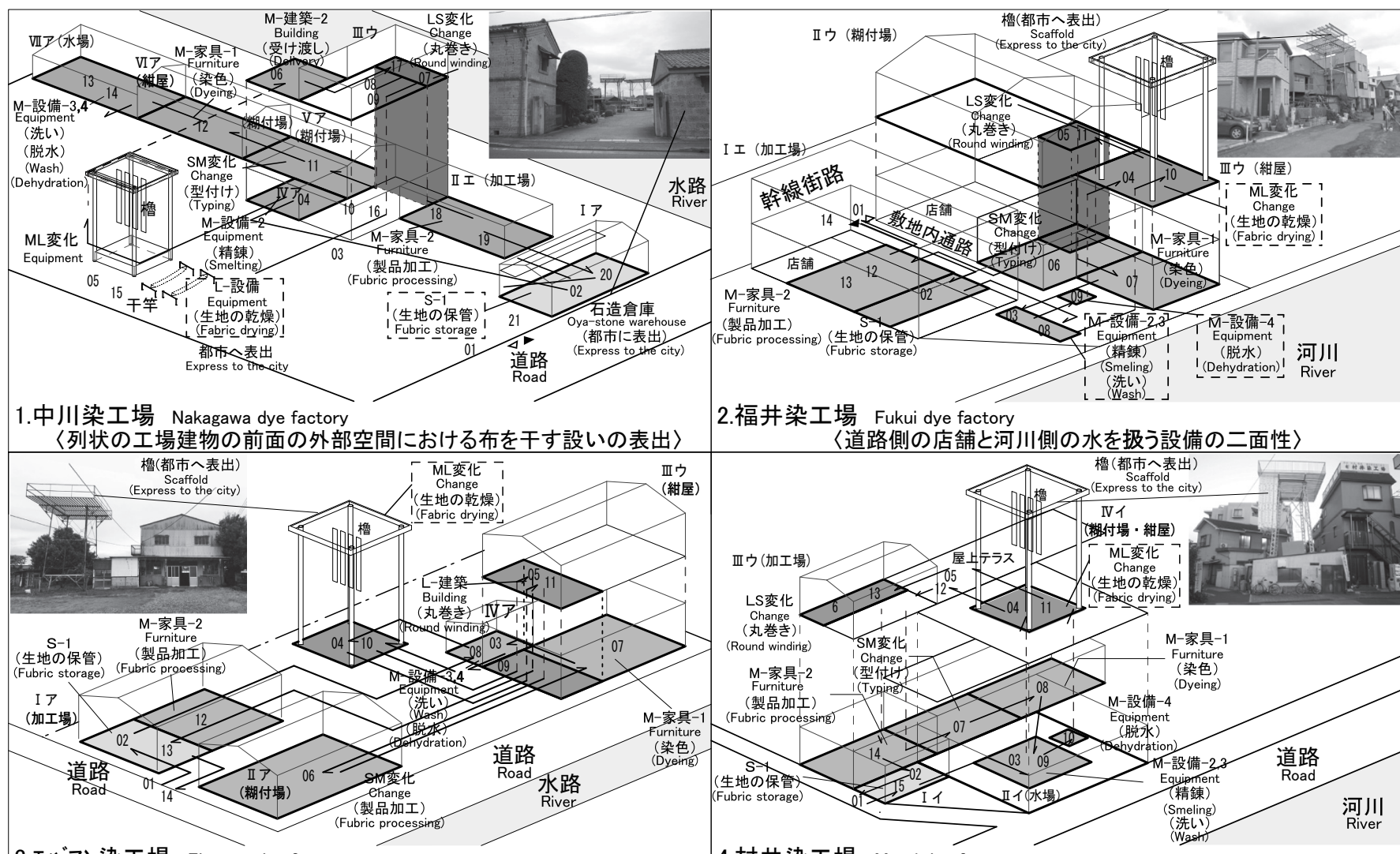

2.福井染工場 Fukui dye factory

〈道路側の店舗と河川側の水を扱う設備の二面性〉

3.エバマン染工場 Ebaman dye factory
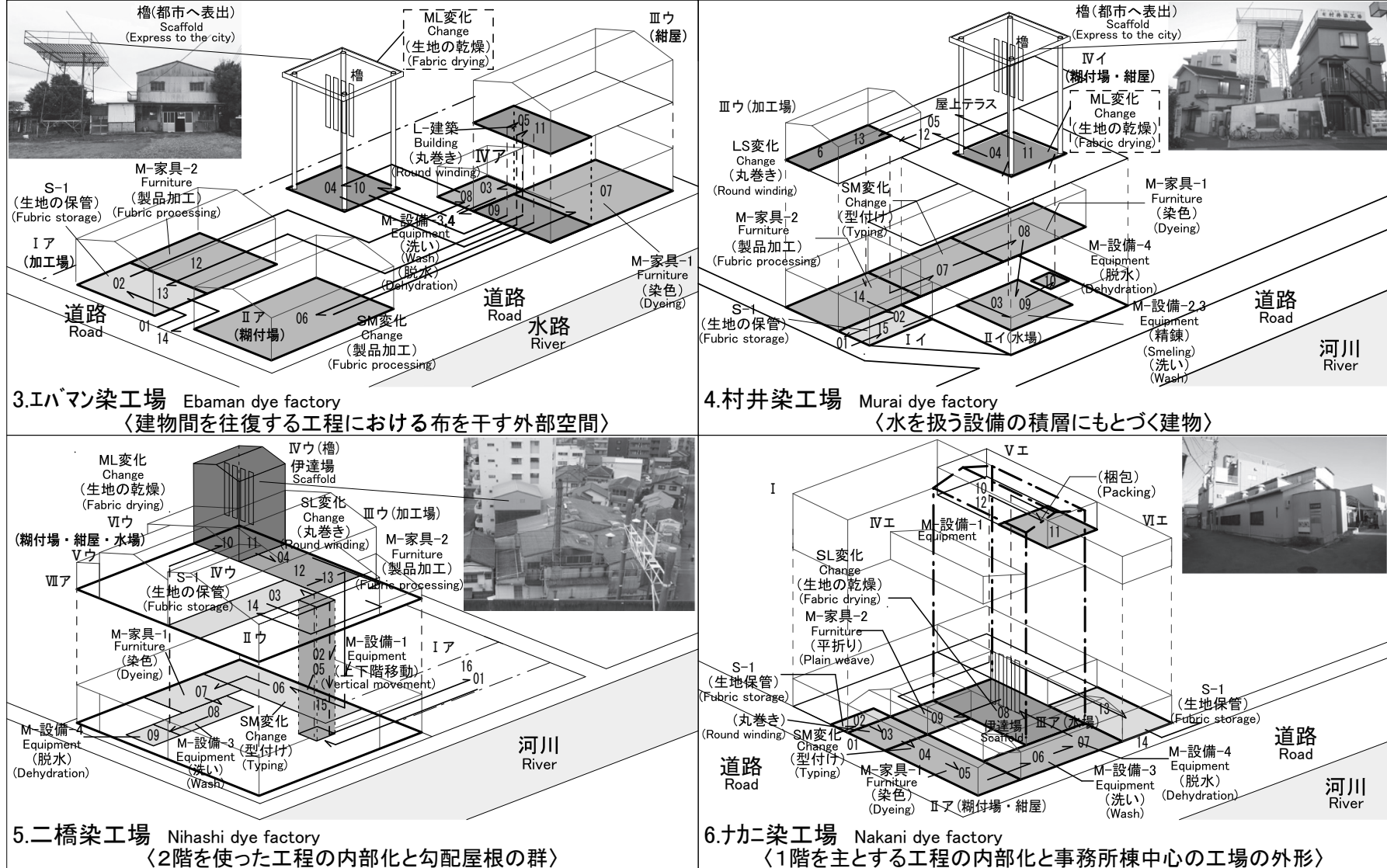

4.村井染工場 Murai dye factory

〈水を扱う設備の積層にもとづく建物〉

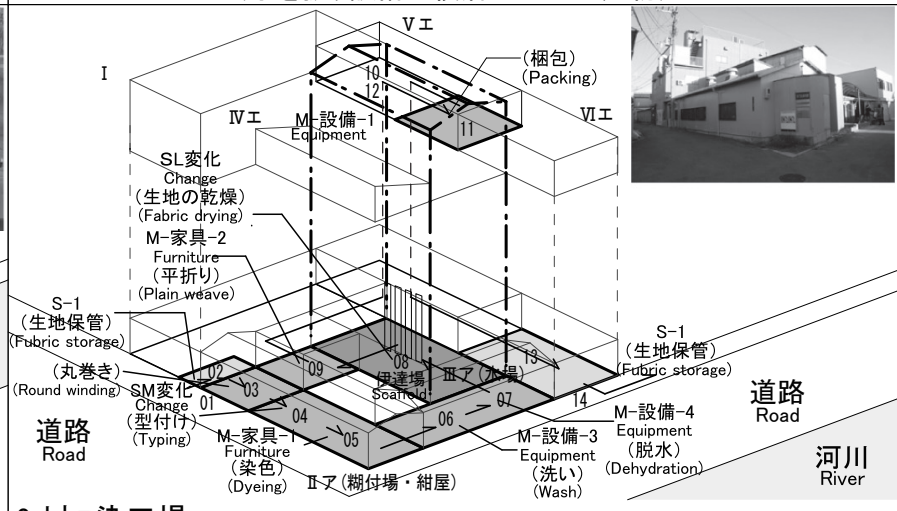

6.ナ力二染工場 Nakani dye factory

〈1階を主とする工程の内部化と事務所棟中心の工場の外形〉

Fig.6 Spatial composition of dye factory

図 6 染工場の空間構成

表注) 数字は工程を、矢印は工程の順序を示す。太線は建物の棟を、破線で囲まれた設いは都市空間への表出が見られるものを示す 
て、敷地奥の水場（IV）に運ばれ精錬され（03）、櫓で干される(04)。 乾いた布は、建物内（III）の階段で 2 階に運ばれ、丸巻きされる (05)。 そして、再び外部空間を通って、敷地入口の建物（II）に運ばれ、 型付けされる $(06)$ ここでは、この工場の主な生産物である捺染の 型付けも行わ机ている。その後、三度目の外部空間を通過して、敷 地奥の丸巻きをした建物の 1 階で染色される (07)。ここでも、同じ 空間で捺染の工程が行われている。染められた布は、再び水場で洗 われ、櫓で干される（10）。乾燥した布は丸巻きされ、四度目に外 部空間を通り、最初に生地が保管されていたのと同じ建物（I）で、 手拭いに製品加工され（12）、保管された後に出荷される。

このように、エバマン染工場では、河川に面さず、櫓のある外部 空間を挟んで、布が行き来する中で工程が展開するのが特徵である。

村井染工場（No.4）：本染工場は、東京都江戸川区に立地し、 敷地面積が最も小さな染工場である。角地で二面接道し、一方の道 路の先に河川が位置しており、櫓を広範囲から眺めることができる。 生地はやはり丸巻き (S-1) の状態で、敷地角の小さな保管庫 ( I ) で保管される (02)。櫓の柱脚が、水場の建物（II）を貫通し、水槽 の四隅が基礎となっている。布はこの水槽で精錬され（03）、階段で 屋上に運び、櫓で乾燥される（04）。つまりここでは、布を洗って干 す水を扱う工程が、狭小な敷地の中で、櫓と水槽が上下に一体化す る設いで実現されている。乾いた布は、隣の建物（IV）の屋上のテ ラスに投げ渡され（05）、横の建物（III）の 2 階で丸巻きされる (06)。 丸巻きの布は、階段で 1 階に運ばれ、型付け (07) と染色 (08) が 屋上テラス下の空間で行われる。染められた布は、再び水槽で洗われ、 その上部の櫓で干される(11)。乾燥した布は、再び丸巻きされ (13)、 1 階に階段で運ばれて、手拭いの製品に加工される（14）。製品は、 最初の保管庫（Ｉ）で保管され（15）、出荷される。

このように、村井染工場は、狭小な角地において、水を扱う水槽 と櫓が上下に積層されることで一体的な設いとなり、布が干される 光景を、広範囲から眺めることができるという特徴がある。

二橋染工場（No.5）：本染工場は、静岡県浜松市に立地する。 敷地は中川染工場の次に広いが、大半に建物が建ち、作業のための 外部空間はほとんどなく内部化されている。エバマン染工場と同じ 捺染も行い、なかでも機械化されたローラー捺染を主に生産し、注 染は工場の一部で行われている。生地は、精錬された平折りの状態 $(\mathrm{Mb})$ で、搬入路を通り建物（I）に搬入される $(01)$ 。その後、昇 降機で 2 階へ運ばれ（02）、隣の建物（III）で丸巻きされると（04）、 再び昇降機で 1 階へ運ばれる (05)。さらに隣の建物（VI）で、型付 け（06）と、染色（07）、染色後の洗い（08）までが、同じ空間で 行われる。洗われた布は、階段で 2 階に運ばれて、乾燥される (10)。 これまでに述べた工場が、屋外の櫓で布を干すのに対して、この工 場では建物の内部で布が干され、この場所は伊達場（だてば）注15) と呼ばれている (IV)。乾燥した布は、一旦平折りされ (11)、隣の 建物（III）で、丸巻きされる（12）。丸巻きは床に開口を設けて垂ら す方式ではないため、長い布を扱いやすくするために、一旦、平折 りの工程が挟まれている。丸巻きされた布は、同じ 2 階で、最初に 搬入した建物の上部が加工場になっており（Ｉ）、手拭いに加工され る (13)。製品は 2 階で保管された後に、昇降機で 1 階に下ろされて (15)、搬出される。建物の中央をローラー捺染の機械が占めるため、 これらの工程が外周部で行われている。
以上のように、二橋染工場では、建物内部で工程が完結し、2 階 も多くの工程に用いられながら、工程が表出せず、工場の勾配屋根 の群が表れるのが特徵である。

ナカ二染工場（No.6）： 本染工場は、大阪府堺にあり、昭和 40 年代に創業した比較的新しい染工場である。二橋染工場と同様に、 角地の大半を建物が占め、工程が内部化されている。まず、周辺の 晒工場で精錬された生地が搬入され (01)、3 階建ての事務所建物 （Ｉ）の 1 階の保管庫で保管される。次に、隣の建物（II）に運ばれ、 丸巻き（03）から、型付け（04）、染色（05）まで行われる。その後、 さらに隣の建物 (III) で洗われ(06)、室内の伊達場で乾燥される(08)。 乾燥した布は、平折りにされ (09)、昇降機で2 階に運ばれ (10)、 平折りのまま梱包される (11)。この工場では、手拭いへの製品加 工は行わず、周辺の加工工場との分業が成立している。再び昇降機 で 1 階に下ろされた布は、搬入した建物と別の建物（VI）で保管さ れ（13）、それに面した道路から出荷される。

このように、ナカ二染工場では、精錬や加工の工程が周辺地域で 分業されることで、簡略化された工程が 1 階中心に展開し、3 階建 ての事務所建物を中心に、工場の外形が表れるのが特徴である。

以上の 6 つの染工場における、もの・建築・都市の関係とその表 出についてまとめる。宇都宮の 3 工場は、いずれも櫓で布が干され る光景が都市に表出しており、その中で、中川染工場（No.1）では 広い敷地において、〈列状の工場建物の前面の外部空間における布を 干寸設いの表出〉がみられる。また、福井染工場（No.2）では接道 条件から〈道路側の店舗と河川側の水を扱う設備の二面性〉が成立 しており、エバマン染工場（No.3）では〈建物間を往復する工程に おける布を干す外部空間〉が特徵的である。さらに、最も狭小な敷 地の東京の村井染工場（No.4）では〈水を扱う設備の積層にもとづ く建物〉がみられる。これらの染工場では、布を干す光景がみられ るのに対して、外部空間や屋外の櫓が無く、工程が内部化されるも のがあり、浜松の二橋染工場（No.5）ではく2 階を使った工程の内 部化と勾配屋根の群〉、堺のナカ二染工場（No.6）ではく1階を主 とする工程の内部化と事務所棟中心の工場の外形〉が成立している。

\section{7. 結}

本研究では、地域産業の注染の主産地である宇都宮、東京、浜松、 堺の 6 つの染工場を対象として、そこで生産される布に着目して、 工程をもとに、工場の建築空間における設いと、工場の外形も含め た都市への表出について検討した。

まず、注染の工程は、生地の搬入から、精錬等の準備を経て、型 付けと染色、染色後の洗い、製品の加工から、最終的な搬出まで、 大きく 6 段階の 25 工程に整理することができた。

次に、布と建築空間の関わりについて、まず、布が、丸巻きされ た小さなサイズ、平折りされた中程度のサイズ、一反の布が延ばさ れた大きなサイズといった様々な形態をとることが分かった。また、 こうした布の形態に対応して、床・壁・天井などの建築部位が工夫 され、布を干す櫓などの設備や、作業台など反復される家具などの 特徵があることが分かった。さらに、それらが組み合わされること により、小サイズの布に対応した設いや、中サイズの布に建築・設備・ 家具などが対応する多様な設いなど一定のサイズに対応した設いが あり、その一方で、型付けの際に台の上で布が丸巻きから平折りに 
され、脇に道具や開口のある壁がある組合せや、布を丸巻きする際 の機械と開口の開いた 2 階の床の組合せ、布が延ばされて干される 櫓など、布の形態変化に対応した特徵的な設いがあることを明らか にした。

さらに、染工場の外形について建物の組合せを検討した。階数は、 平屋と 2 階建ての組合せが大半で最大で 3 階建てがあり、屋根形状 は、陸屋根に比べて勾配屋根が多く、また、構造は、木造のみ、鉄 骨のみ、鉄骨の建物と木造の建物をあわせ持つ工場がみられた。こ れらの特徵をもとに染工場の建物の外形を 4 つのパタンに整理した。

最後に以上を総合して、各染工場における「もの・建築・都市」 の関係を検討した。その結果、宇都宮の 3 工場は、いずれも櫓で布 が干される光景が都市に表出しているが、その中でも、大規模な敷 地に建物が外部空間を伴って建つ染工場では、〈列状の工場建物の前 面の外部空間における布を干す設いの表出〉、〈建物間を往復する工 程における布を干す外部空間〉という特徵が成立していることが明 らかになった。これに対して、小規模な敷地の過半に建物が建つ染 工場では、宇都宮の市街地における〈道路側の店舗と河川側の水を 扱う設備の二面性〉、東京における狭小な敷地を工夫した〈水を扱う 設備の積層にもとづく建物〉という光景の表出があり、その一方で、 布を干す光景が表出せず、浜松における〈2 階を使った工程の内部 化と勾配屋根の群〉、堺における〈1階を主とする工程の内部化と事 務所棟中心の工場の外形〉という特徵が成立していることが明らか になった。

これらの特徴は、染工場において、布というものと、それが製品 になるまでの建築空間、さらに、河川の水を利用するための立地を 含めた都市空間との関係が成立していることを示している。このこ とから、地域産業におけるものづくりの空間は、単なる生産施設と しての存在を超えて、都市の事物の有機的な関係性を内包するもの として、今後の建築文化や地域活性化において重要な位置付けをな すと考えられる。

\section{謝辞}

本研究にご協力を頂いた中川染工場、福井染工場、エバマン染工場、 村井染工場、二橋染工場、ナカ二染工場、および宇都宮美術館専門 学芸員の橋本優子氏に感謝の意を表します。

\section{Acknowledgments}

We express appreciation to Nakagawa Dye Factory, Fukui Dye Factory, Ebaman Dye Factory, Murai Dye Factory, Nihashi Dye factory, Nakani Dye Factor, and Ms. Yuko Hashimoto in Ustumomiya Museum of Art who cooperated in this research.

注

注 1）産業近代化の過程を物語る建築物等の歴史的価値の顕在化とそれによる 地域活性化を目的として、2007〜2008 年に経済産業省によって「近 代化産業遺産」が認定された。また、富岡製糸場と絹産業遺産」(2014 年)、「明治日本の産業革命遺産 製鉄·製鋼、造船、石炭産業」(2015 年) などが世界遺産に登録されている。

注 2) 全国 7 都市による「全国工場夜景サミット」（2010 年から毎年）の開催 や、工場建築の写真集（参考文献 4) の刊行などが近年盛んである。

注 3)「設い」とは、辞書によ机ば、「しつらい【設い】(1)設けととのえること。 飾りつけること・設備。しつらえ。(2) (「室礼」「舗設」は当て字) 請客 饗宴・移転・女御入内その他、晴の儀式の日に、寝殿の母屋捛よび廂に 調度類を整えること」(建築大辞典，彰国社）とあり、本論文では、(1)
の定義を前提に、研究テーマのものづくり空間において、工程に応じて、 道具・家具・設備・建築部位等を「設けととのえる」ことを意味してい る。また、(2にあるように「室礼」や「舗設」という表記も用いられる が当て字であるため「設い」と表記し、さらに「設え」は動詞形「設え る」として主に用いられることから、名詞形で一般的な「設い」という 表記とした。

注 4) 本稿は、参考文献 $11 ， 12$ をもとに加筆修正したものである。

注 5）宇都宮美術館平成 27 年度・館外プロジェクト「地域産業とデザイン〜 宮の注染を拓く〜」が、宇都宮美術館, 宇都宮大学, GK グラフィック ス，中川染工場の協働により、2015 年 6 月から開始され、その展覽会 が 12 月に宇都宮大学峰ヶ丘講堂 (大正 13 年筑) を会場として開催さ れた。その成果は、参考文献 13 にまとめられている。

注 6)「注染・和晒・整理 全国産地工場名簿」（1988 年，参考文献 16）には、 注染の部として、「東京・埼玉・神奈川・栃木地区」、浜松地区」、「名 古屋地区」「大阪・柏原・堺地区」の記載があり、これらの染工場につ いて所在地による地図上の確認および電話による確認をしたところ、神 奈川、名古屋では現存せず、埼玉では 1 件のみであった。そのため、複 数の注染の工場が確認された東京、栃木 (宇都宮)、浜松、大阪を主産 地とした。

注 7）染工場数の推移㧍よび各地の概要は、参考文献 13,14 および聞き取り 調査をもとに作成した。

注 8) 本研究では、まず宇都宮に現存する 3 件の染工場を調査し、その特性を 全国的に比較するために他都市の代表的な染工場を 1 件ずつ調査した。 宇都宮では、No.1 中川染工場は、敷地面積·延床面積・生産量ともに最大、 No.2 福井染工場は敷地が最小、No. 3 エバマン染工場は戦後に郊外移転 した比較的新しい工場である。これをもとに、東京の狭小敷地における No.4 村井染工場、浜松の大規模な敷地面積・延床面積の No.5 二橋染 工場、大阪府堺の比較的新しく生産量が多いNo.6 ナカ二染工場を調査 した。

注 9）捺染とは、比較的小さなサイズの布に型紙を用いて刷毛やへラで印を染 める印染 (しるしぞめ) の一種であり、本研究で対象としている反物を 畳んで注ぎ染める注染とは技法が異なる。

注 10) 東京で現在稼動する染工場は、対象とした村井染工場 (江戸川区) 以外に、 伊勢保染工所 (江戸川区)、鍵善（葛飾区）、旭染工場（足立区）である。

注 11）浜松で現在稼動する染工場は、対象とした二橋染工場以外に、曳馬染 工場、武藤染工、和田染工などである。

注 12）浸染とは、布を染液に浸けて全体を染める技法である。

注 13）堺で現在稼動する染工場は、資料としたナカ二染工場以外に、竹野染工、 協和染晒工場、西川由染酔工場である。

注 14）表 3 中の記号は、こ扎以降の本文でも用い、凡例は次の通りである。 工程について、 A : 生地の搬入 ·保管、B：染色前準備、C：染色、D : 染色後洗い、 $\mathrm{E}$ : 製品の仕上げ・加工、 $\mathrm{F}$ ：製品の保管・搬出、また布 の状態について、移 : 移動、保 : 保管、加 : 加工。

注 15）No.5 二橋染工場と No.6 ナカ二染工場では、布を櫓で乾燥する工程を 「伊達」と呼び、その場所を「伊達場」と称している。「伊達」という言 葉には「見せびらかす」という意味があるため、染めた布を吊り下げる ことを中部圈から関西圈ではそう呼んでいると考元れる。

\section{参考文献}

1) Le Corbusier (Yoshizaka, T. Trans.): Towards a New Architecture, Kajima Institute Publishing, 1967.12 (in Japanese) ル・コルビュジェ, 吉阪隆生訳 : 建築を目指して, 鹿島出版会, 1967.12

2) Rudofsky, B. (Watanabe T. Trans.): Architecture Without Architects, Kajima Institute Publishing, 1984.1 (in Japanese) バーナード・ルドフスキー, 渡辺武信訳 : 建築家なしの建築, 鹿島出版会, 1984.1

3) Becher, B, and Becher, H. (photography), Zweite, A. (text): Typologies of Industrial Buildings, MIT Press, Cambridge, 2004.3

4) Oyama, K. (photography) and Ishii, S. (text): Kojo Moe, Tokyo Shoseki, 2007.3 (in Japanese) 大山顕（写真）, 石井哲（文）：工場萌元, 東京書籍, 2007.3

5) Yamada,T. and Oba,O.: ON THE ARCHITECTURAL COMPOSITION AND THE DEVELOPMENT PROCESS OF THE HEADQUARTERS AND MAIN FACTORY OF GUNZE RAW SILK MFG. CO. LTD., Journal of 
Architecture and Planning (Transactions of AIJ), Vol. 75, No.649, pp.717-726, 2010.3 (in Japanese)

山田智子, 大場修: 郡是製絲株式會社本社・本工場の建築構成と発展過程, 日本建築学会計画系論文集，第 75 巻，第 649 号, pp.717-726, 2010.3

6) Hirakida, K. and Onomichi, K.: ON THE FACTORY AND DESIGNER IN THE JAPANESE GOVERNMENT-CONTROL YAWATA IRON WORKS FROM THE TAISHO ERA TO THE EARY SHOWA ERA, No. 3 A study on the introduction and development process of steel structure architecture in Japan, Journal of Architecture and Planning (Transactions of AIJ), Vol.74, No.635. pp.249-255, 2009.1 (in Japanese)

開田一博, 尾道 建二：大正期から昭和初期における官営八幡製鐵所の工 場建築と設計者について：日本における鉄骨構造建築の導入と発展過程 に関する研究 その 3 , 日本建築学会計画系論文集, 第 74 巻, 第 635 号, pp.249-255, 2009.1

7) Isoda, K.: PLANNING OF COTTON SPINNING MILL OF KUMAMOTO BOSEKI CO.,LTD., Journal of Architecture and Plannning (Transactions of AIJ), Vol.72, No.615, pp.199-206, 2007.5 (in Japanese)

磯田桂史：熊本紡績工場建物の平面の計画について, 日本建築学会計画系 論文集, 第 72 巻，第 615 号, pp.199-206, 2007.5

8) Tsujihara, M. and Imamura, S.: INFLUENCE OF CONSTRUCTION OF SUGAR REFINERY FACTORIES ON AREA DEVELOPMENT IN OKINAWA PREFECTURE BEFORE WORLD WAR II, Journal of Architecture and Plannning (Transactions of AIJ), Vol. 82, No.737, pp.1859-1869, 2017.7 (in Japanese)

辻原万規彦, 今村仁美 : 戦前期の沖縄における製糖工場とその建設が地域に 与えた影響, 日本建築学会計画系論文集, 第 82 巻, 第 737 号, pp.1859$1869,2017.7$

9) Ohkubo, T., Hiraoka, S. and Kobayashi, M.: HISTORICAL DESIGN SURVEY OF INCINERATION PLANTS, Case study in 3 major cities of Kansai area, Journal of Architecture, Plannning and Environmental Engineering (Transactions of AIJ), Vol. 62, No.497, pp.213-220, 1997.7 (in Japanese)

大窪健之, 平岡真, 小林正美 : 清掃工場のデザインの変遷とその背景に関 する調査研究 : 関西 3 都市の事例を中心として, 日本建築学会計画系論文 集, 第 62 巻, 第 497 号, pp.213-220, 1997.7

10) Tsukamoto, A., Tsukamoto, Y. et al.: Windows in Workshops of Handwork viewed from Interrelation between Human, Things and Natural Resources (1), Summaries of Technical Papers of Annual Meeting, Architectural Institure of Japan, History and Theory of Architecture, pp.25-26, 2016.7 (in Japanese)

塚本晃子, 塚本由晴, 他 5 名: 手仕事の工房における空まわりの空間的特 徵, 人・モノ・自然要素の連関からみた手仕事の工房における空（1）, 日 本建築学会大会学術講演梗概集, 建築歴史・意匠, pp.25-26, 2016.7

11) Yasumori, A. and Fukuzawa, J.: Architectural Setting in relationship to Cloth of Dye Factory, Study on Manufacturing Space of Local Industry (1), Summaries of Technical Papers of Annual Meeting, Architectural Institure of Japan, History and Theory of Architecture, pp.403-404, 2017.7 (in Japanese)

安森亮雄, 福沢潤哉: 染工場における布からみた設え, 地域産業における ものづくりの空間に関する研究 $(1)$, 日本建築学会大会学術講演梗概集 , 建 築歴史・意匠, pp.403-404, 2017.7

12) Fukuzawa, J. and Yasumori, A.: Spatial Composition and Townscape of Dye Factory, Study on Manufacturing Space of Local Industry (2), Summaries of Technical Papers of Annual Meeting, Architectural Institure of Japan, History and Theory of Architecture, pp.405-406, 2017.7 (in Japanese)

福沢潤哉, 安森亮雄: 染工場の空間構成と景観, 地域産業におけるものづ くりの空間に関する研究 (2), 日本建築学会大会学術講演梗概集, 建築歴 史・意匠, pp.405-406, 2017.7

13) Utsunomiya Museum of Art: Reserch Papers Outreach Project 2015 Local Industry and Design, The Revival of CHUSEN Dyeing in Utsunomiya, 2016.3 (in Japanese)
宇都宮美術館 : 宇都宮美術館平成 27 年度・館外プロジェクト 地域産業と デザイン〜宮の注染を拓く〜論集, 宇都宮美術館, 2016.3

14) Saitama Prefectural Museum of History and Folklore: Saitama-ken Minzoku Kougei Chousahokoku, Saitama no Chusen, 2007.3 (in Japanese)

埼玉県立歴史と民俗の博物館：埼玉の注染, 埼玉県民俗工芸調査報告, 2007.3

15) Nishizu, Y., Konishi, A., Kaijima, M. et.al.: Typology of Kyozome Machiya Viewed from Renovation Process and Background -Architectural Characteristics of Kyozome Machiya and the Modernization of Industry(1)-, Summaries of Technical Papers of Annual Meeting, Architectural Institure of Japan, History and Theory of Architecture, pp.555-556, 2017.7 (in Japanese)

西津侑杜, 小西葵, 貝島桃代, 他 2 名: 京染町家の増改築過程とその背景 からみた類型 産業の近代化と京染町家の建築的特徵 (1)，日本建築学会 大会学術講演梗概集, 建築歴史・意匠, pp.555-556, 2017.7

16) Sen-i Keizai Shinbunsha: Chusen Wazarashi Seiri Zenkoku Sanchi Koujou Meibo, Sen-i Keizai Shinbunsha, 1988.1 (in Japanese) 繊維経済新聞社: 注染・和晒・整理 全国産地工場名簿, 繊維経済新聞社, 1988.1 


\title{
SPATIAL SETTING AND ITS APPEARANCE IN THE DYE FACTORY \\ OF CHUSEN FROM THE VIEWPOINT OF CLOTH
}

Study on Interrelation between Thing, Architecture and City in Manufacturing Space of Local Industry

\author{
Akio YASUMORI ${ }^{* 1}$, Junya FUKUZAWA ${ }^{* 2}$ and Takuya TSUKAMOTO ${ }^{* 2}$ \\ ${ }^{* 1}$ Prof., Graduate School of Engineering, Chiba Univ., Dr.Eng. \\ ${ }^{*}$ Institute of New Architecture Inc., M.Eng.
}

\begin{abstract}
Amongst all the local industries, the pour-dyeing operates mass production with some handicraft; pouring chemical dye on the folded cotton by hand makes patterns for towels and kimonos. These dyeing factories have developed along the urban river because of its use of water and great transportation links. The process and the fabric forms, such as folded or spread, determine the settings. These spatial settings disclose the close relationship between the things, architecture, and city. This research targets the dyeing factories, and aims to clarify the spatial settings from the viewpoint of the thigs used and the characteristics shown in the townscape caused by them. This paper specifically targets 6 factories from the main producing areas: 3 factories from Utsunomiya, Tochigi; 1 from around Arakawa River in Tokyo; 1 from Hamamatsu, Shizuoka; and 1 from Sakai, Osaka.
\end{abstract}

First, manufacturing flow is grasped and organized; it is divided into 6 phases and 25 steps. The condition of the fabric is classified as the preservation, the processing, and transportation to the next process. Secondly, the spatial settings and the fabric forms are organized as a set. The usual size of the fabric is $37 \mathrm{~cm}$ by $12.5 \mathrm{~m}$ which is just enough to make one kimono.There are 3 different forms of the fabric; rolled up into a small size (S), folded flat into a middle size (M) and largely spreaded form (L). Also, the architectural parts such as floors, walls, ceilings, roofs, etc. are reviewed and organized. With all these factors, 13 "patterns of setting" were derived. Thirdly, the composition of factory shapes is reviewed and organized into 5 patterns by the number of the floors, the shape of the roofs and the structure.

Finally, the relationship between things, architecture, city, and surroundings were clarified. In the Nakagawa dye factory in Utsunomiya (No.1), the stone warehouse, creating the local town scenery, is the starting and the endpoint of the site. The two story building being the center among the seriate of one-story buildings, and the fabrics hung on the scaffold and the rods are exposed to the street and riverside. The Fukui dye factory (No.2), which locates on a small site, the storefront is exposed on the street and washing and drying equipment on the riverside. The Ebaman dye factory (No.3), which doesn't face a river, has a scaffold in the middle, and the manufacturing flow expands as the fabric comes and goes from one building to another. The Murai dye factory in Tokyo (No.4) is located in a small corner lot. The water tank and the scaffold are stacked as a unified form, and the scenery of the fabrics hanging from there makes the landmark. In the Nihashi dye factory in Hamamatsu (No.5), all the process are completed inside the building. The variety of roof shapes are shown instead of the equipment being exposed. The building of the Nakani dye factory in Osaka (No.6) is piled up over the entire site instead of spreading, and the scaffold in the middle makes a distinguishing characteristic of the site.

The results stated above are the re-examining of the things, the architecture in which things are produced, the city, and the natural environment. The re-establishment of the relationship between the region and the things, which have been divided by industries since modern times, has a significant value. 